\title{
Percutaneous Reconstruction of the Ulnar Collateral Ligament of the Metacarpophalangeal Joint of the Thumb: Technique and Results
}

\section{Reconstrucción percutánea del ligamento colateral ulnar de la articulación metacarpofalángica del pulgar: Técnica y resultados}

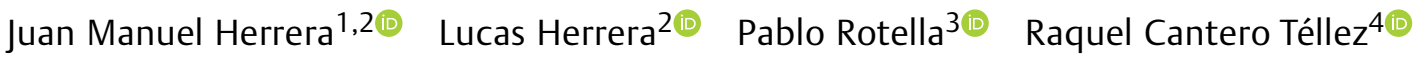

Jimena Castellanos ${ }^{5(1)}$ Fernando Vázquez ${ }^{6(0)}$

${ }^{1}$ Hand Surgery Unit, Centro Privado de Cirugía del Pie y la Mano (CEPYM), Tucumán, Argentina

2 Hand Surgery Unit, Centro Integral de Ortopedia y Traumatología

Address for correspondence Juan Manuel Herrera, MD, Unidad de Cirugía de Mano, CIOT y CEPYM, Tucumán, 4000, Argentina (CIOT), Tucumán, Argentina

${ }^{3}$ Hand Surgery Unit, Instituto Rotella, Tucumán, Argentina

${ }^{4}$ Hand Clinic, Centro Tecan, Universidad de Málaga, Málaga, Spain

${ }^{5}$ Occupational Therapy, Hand therapy, Tucumán, Argentina

${ }^{6}$ Hand Surgery Unit, Clínica Mayo, Tucumán, Argentina

Rev Iberam Cir Mano 2020;48:101-108.

Abstract
Keywords
- metacarpophalangeal
joint
- thumb
- ulnar collateral
ligament
- percutaneous

Resumen
Objectives The present study aims to describe a new percutaneous technique for the reconstruction of the ulnar collateral ligament of the metacarpophalangeal joint of the thumb with a tendon graft, and to evaluate the functional outcomes and stability six months postoperatively.

Material and methods The percutaneous ligamentoplasty technique was performed with a palmaris longus tendon graft and tenodesis screws in 6 patients with ulnar instability of the thumb ( $>30^{\circ}$ degrees of radial deviation) for more than 6 weeks. Range of motion, grip strength, and pinch strength (lateral/key pinch, tip pinch, and palmar pinch) were assessed in comparison to the contralateral limb, as well as the Quick Disabilities of the Arm, Shoulder and Hand (DASH) score.

Results At 6 months, the joint movement was of $100 \%$, the grip strength was of $94.8 \%$, the key pinch was of $95 \%$, the palmar pinch was of $85.7 \%$, and the tip pinch was of $93.5 \%$ compared to the contralateral limb. The internal tilt was of $14^{\circ}$ compared to $9^{\circ}$ at the contralateral limb. The Quick DASH score decreased from 24.2 to 2.6 points. Conclusion We devised this versatile surgical procedure to obtain early mobility with the advantages related to the percutaneous techniques.

Objetivo El objetivo de este trabajo es presentar una nueva técnica percutánea de reconstrucción del ligamento colateral ulnar de la articulación metacarpofalángica del received

July 27,2020

accepted

September 2, 2020
DOI https://doi.org/

10.1055/s-0040-1719014. ISSN 1698-8396.
Copyright $\odot 2020$ Thieme Revinter

Publicações Ltda, Rio de Janeiro, Brazil
License terms

(c) (i) $\ominus$ (\$) 


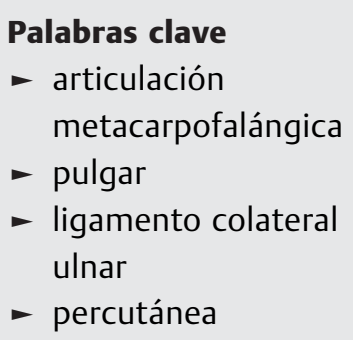

pulgar con injerto tendinoso, y evaluar los resultados funcionales y la estabilidad a los seis meses postoperatorios.

Material y métodos Se realizó la técnica de ligamentoplastia percutánea con injerto de tendón del músculo palmar largo y tornillos de tenodesis en 6 pacientes que presentaban inestabilidad ulnar de pulgar (con más de $30^{\circ}$ de desviación radial) con más de 6 semanas de evolución. Se valoró el rango movilidad, la fuerza de agarre (prensión), y la fuerza de pinzas (llave, palmar, y tres puntos) en comparación al miembro contralateral, así como la escala de Quick Disabilities of the Arm, Shoulder and Hand (DASH).

Resultados A los 6 meses, el movimiento articular fue del 100\%, la fuerza de agarre fue del $94.8 \%$, la pinza llave, del $95 \%$, la pinza palmar, del $85,7 \%$, y la pinza 3 puntos, del $93.5 \%$ en comparación al miembro contralateral. El bostezo interno fue de $14^{\circ}$ en comparación con $9^{\circ}$ en el miembro contralateral. El Quick DASH disminuyó de 24.2 a 2.6 puntos.

Conclusión Ideamos este procedimiento quirúrgico versátil para obtener movilidad precoz y las ventajas que nos otorgan las técnicas percutáneas.

\section{Introduction}

Metacarpophalangeal (MCP) instability of the thumb was first described by Campbell ${ }^{1}$ in 1955 as a chronic condition known as "gamekeeper's thumb;" later, in 1962, a Swedish surgeon named Betil Stener ${ }^{2}$ reported the pathophysiology of ulnar collateral ligament (UCL) injuries, describing the mechanism of UCL rupture as resulting from a forced radial deviation (abduction) with interposition of the aponeurosis of the adductor pollicis, which prevents its healing.

Clinically, this injury results in pain, instability, and decreased pinch and grip strength, which can progressively lead to osteoarthritis of the MCP joint. ${ }^{3}$ Chronic instability is assessed similarly to acute instability. The physical examination is based on valgus stress maneuvers and comparison with the contralateral joint. ${ }^{4}$ The diagnosis is completed by radiographic images to rule out bone avulsions, volar subluxation of the first phalanx, and osteoarthritis. Both magnetic resonance imaging and ultrasound are used to confirm the diagnosis, although there is no consensus on which is more accurate. ${ }^{5}$

The literature describes a number of static and dynamic techniques for UCL reconstruction, including capsular plasty, dynamic tendon transfer, and free tendon grafting. ${ }^{6-11}$ However, adapting to implant developments and the trend toward less aggressive procedures, the present study aims to describe a versatile surgical technique for anatomical UCL reconstruction with a palmaris longus tendon graft; as a percutaneous surgery, it produces less scar tissue, reduces the number of complications, including infections, adhesions, and stiffness, and accelerates the return to work and sport activities. $^{12-15}$

\section{Material and Methods}

From March to August 2019, surgery was performed on 6 patients with UCL injury. All subjects were male, with a mean age of 35.3 years. The patients were included in the present descriptive cross-sectional cohort study if they presented UCL lesions with radial deviation greater than $30^{\circ}$ ( - Fig 1.A), greater than $15^{\circ}$ compared to the contralateral limb, or with no firm final stop on the physical examination, and evolving for more than 6 weeks since the trauma. ${ }^{16}$ The subjects with osteoarthritis of the MCP joint, multidirectional stability and/or chronic fixed subluxation were excluded. ${ }^{17}$ No patient had fractures or associated injuries.

The injuries were caused by MCP abduction and hyperextension resulting from occupational activities (four cases), sports (one case), and domestic accidents (one case).

The evaluation criteria comprised active mobility in degrees, radial deviation or internal tilt in degrees, fist strength, three types of MCP grip strength (key, palmar and tip strength), and the Quick Disabilities of the Arm, Shoulder and Hand (DASH) score. These criteria were evaluated immediately before surgery, six months after the procedure, and they were also compared to the contralateral, uninjured thumb.

Upon physical examination, the average radial deviation in the MCP joint was of $40^{\circ}$ ( - Fig. 1-A) both in extension and flexion. On average, the active mobility in flexion was of $45^{\circ}$ compared to the contralateral active mobility of $55^{\circ}$, measured with a finger goniometer. The grip strength was decreased by $61 \%$ compared to the contralateral grip, and the key, palmar, and tip strengths were decreased by $47 \%$, $36 \%$, and $42.8 \%$ respectively, compared to the contralateral limb. The strength was measured in $\mathrm{kg}$ with Jamar and pinch dynamometers.

An extension stress radiograph showed an average internal tilt of $40^{\circ}$ (-Fig. 1.B), which was consistent with the findings of the physical examination. Magnetic resonance imaging (Philips 3-Tesla scan, Philips, Amsterdam, Netherlands) confirmed UCL rupture in every patient. 


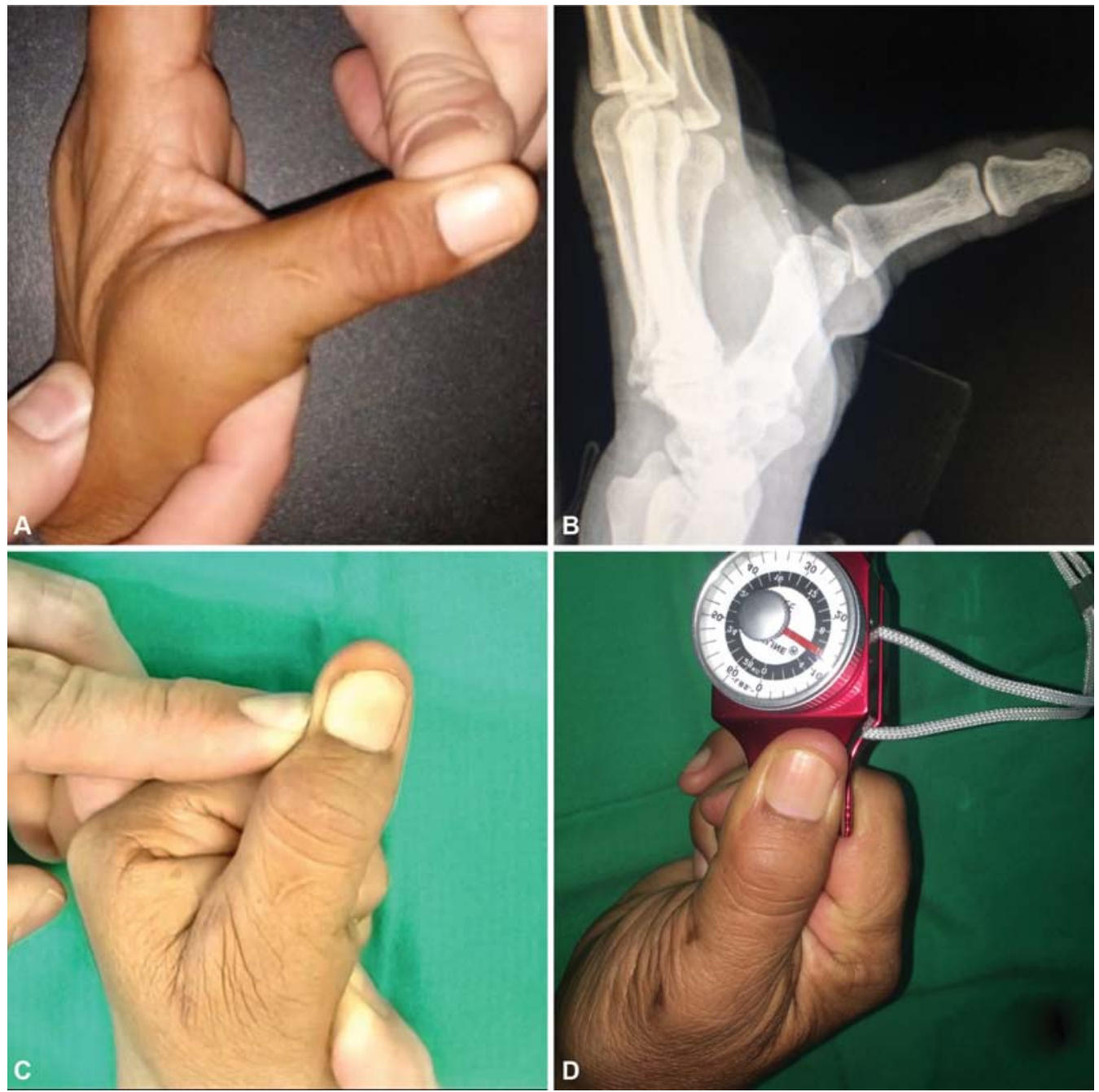

Fig. 1 Clinical (A) and radiological (B) instability greater than $30^{\circ}$ prior to surgery. Postoperatively, stability (C) and strength are recovered (D). (-Video 1)

\section{Surgical Technique}

The patient is placed in supine position, and axillary block and limb ischemia are performed. A tendon graft from the palmaris longus (- Fig 2.A), with approximately $11 \mathrm{~cm}$, is obtained. Under fluoroscopic control, a 1-mm Kirschner (K) wire is placed dorsal to the rotational axis of the metacarpal head, and another $1-\mathrm{mm} \mathrm{K}$ wire is placed volar to the center of the base of the proximal phalanx; both locations are anatomical attachment sites for the UCL (-Fig 2.B-C). Three-mm approaches are made around the radial and ulnar side wires, the subcutaneous tissue is released with mosquito forceps, and, using a soft-tissue protector to spare the dorsal sensitive branches, both tunnels are drilled with a 3.2$\mathrm{mm}$ drill bit. The tendon graft is traversed through the metacarpal tunnel from radial to ulnar assisted by a guidewire (-Fig 3.A-B). With a curved hemostatic forceps, the tendon is taken from the ulnar metacarpal orifice to the ulnar phalangeal orifice through the subcutaneous tissue ( - Fig 3. C-D). The graft is traversed through a phalangeal tunnel with a guidewire from ulnar to radial (- Fig 3.E-F). A 3-mm tenodesis screw is placed percutaneously in the metacarpal canal using a 1-mm K wire as a guide ( - Fig 4.A-B). Another 3- $\mathrm{mm}$ tenodesis screw is placed percutaneously in the phalangeal canal under $30^{\circ}$ of flexion of the MCP joint and maximum graft tension. A Coban (3M, St. Paul, Minnesota, US) bandage and MCP stabilizing thermoplastic orthosis with palmar Velcro are placed for regular mobilization exercises assisted by an occupational therapist; these exercises consist of MCP and interphalangeal flexion-extension and were started at 7 days. At 6 weeks, progressive resistance exercises were started, and unrestricted exercises were allowed at 12 weeks.

\section{Tricks and tips}

There was no difference in starting the procedure by the metacarpal or the phalangeal tunnels ( - Fig. 5). Graft thickness was adapted to the tunnels, and the gauge was reduced to $2 / 3$ of the width of the graft in two cases. We recommend the use of a No. 16 peripheral venous catheter to quickly locate the exact site in which to place the $K$ wire and use it as a guide for the passage of said K wire. We prefer to place both screws from the radial side to avoid graft friction and wear on the reconstruction (ulnar) side. Three-mm titanium tenodesis screws (Matritec, San Andrés, Buenos Aires, Argentina) 


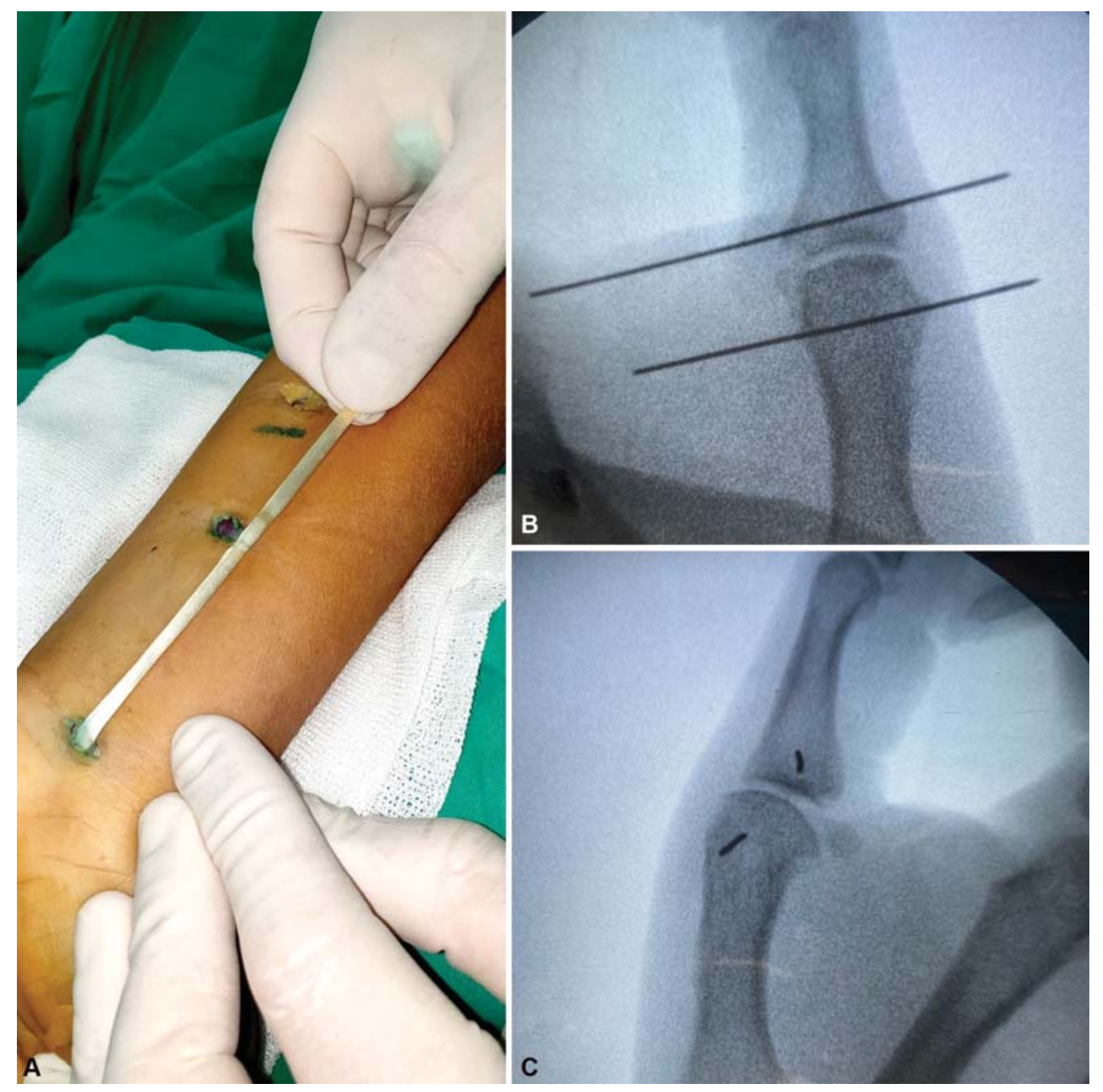

Fig. 2 (A) Palmaris longus tendon graft. (B-C) Placement sites of the Kirschner wires.

and 3-mm biotenodesis screws (Arthrex, Naples, Florida, US) can be used. A soft-tissue protector was used not only in the drilling stage, but also during screw placement to spare the sensitive dorsal branches from the radial nerve. In the absence of the palmaris longus, the extensor indicis proprius (EIP) tendon may be used. ${ }^{18}$

\section{Results}

The total sample analyzed consisted of 6 male patients aged 24 to 51 years (mean \pm standard deviation [SD]: $35.33 \pm 10.25)$. - Table 1 shows the absolute grip and pinch strengths.

The difference between the mean force values before and 6 months after surgery are shown in -Table 2 . All results are significant, with $p<0.001$ (with a $95 \%$ confidence interval).

Theverage score on the Quick DASH was of 24.2 points before surgery, and it decreased to 2.6 points 6 months after the procedure.

Regarding the mobility of the MCP joint 6 months postoperatively, the active flexion measured with a finger goniometer was complete when compared to the contralateral $\operatorname{limb}\left(55^{\circ}\right)$, whereas ulnar deviation under maximum stress (tilt) decreased, on average, $31^{\circ}$ in comparison to the baseline values, being $5^{\circ}$ higher than the average value from the contralateral hand (-Fig 1.C-D)

\section{Discussion}

A paper by Lee et al. ${ }^{19}$ reporting a cadaveric, biomechanical study on tendon grafting fixation in the MCP joint for UCL reconstructions was used as a reference; in it, tenodesis screws were significantly stronger and more rigid compared to bone anchors and buttons, enabling safe, earlier mobility in the postoperative period and decreasing stiffness as a complication. Another group of authors ${ }^{20}$ carried out another biomechanical study in cadavers to compare the outcomes of UCL reconstruction with tendon grafts in four different arrangements (triangular with a proximal base, triangular with a distal base, crossed, and parallel), and showed stabilization of the MCP joint, with no significant differences.

In a biomechanical study, Baskies et al. ${ }^{21}$ found no significant differences in strength when comparing a graft placed in an eight-shape to the use of interference screws.

Rettig et al. ${ }^{22}$ described an open technique using interference screws and a triangular graft arrangement. In 2017, in a 


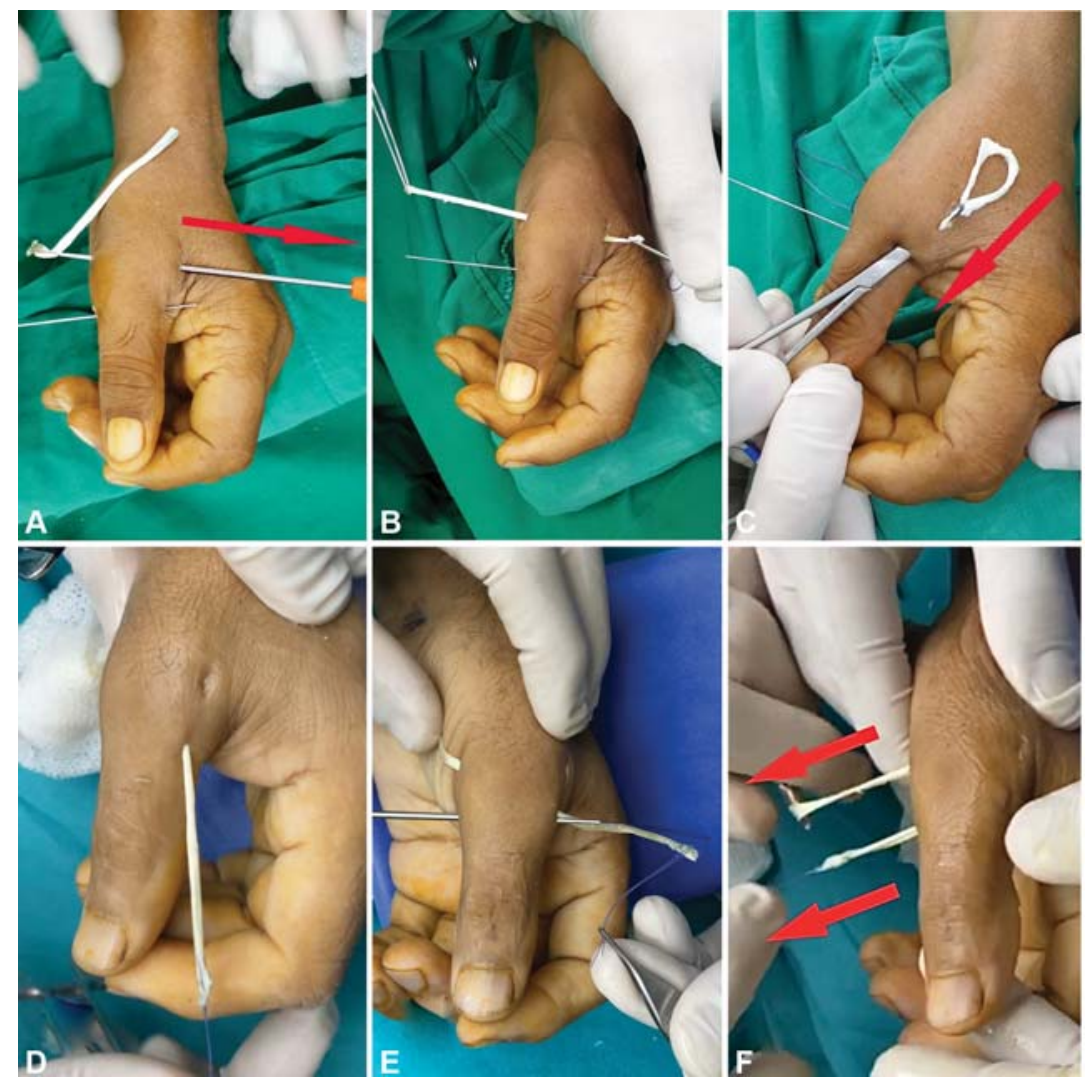

Fig. 3 Tendon graft tunneling. (A-B) Graft passage from the radial to the ulnar sides through the metacarpal tunnel. (C-D) Subcutaneous graft passage. (E-F) Graft passage from the ulnar to the radial sides through the phalangeal tunnel, and graft pull.
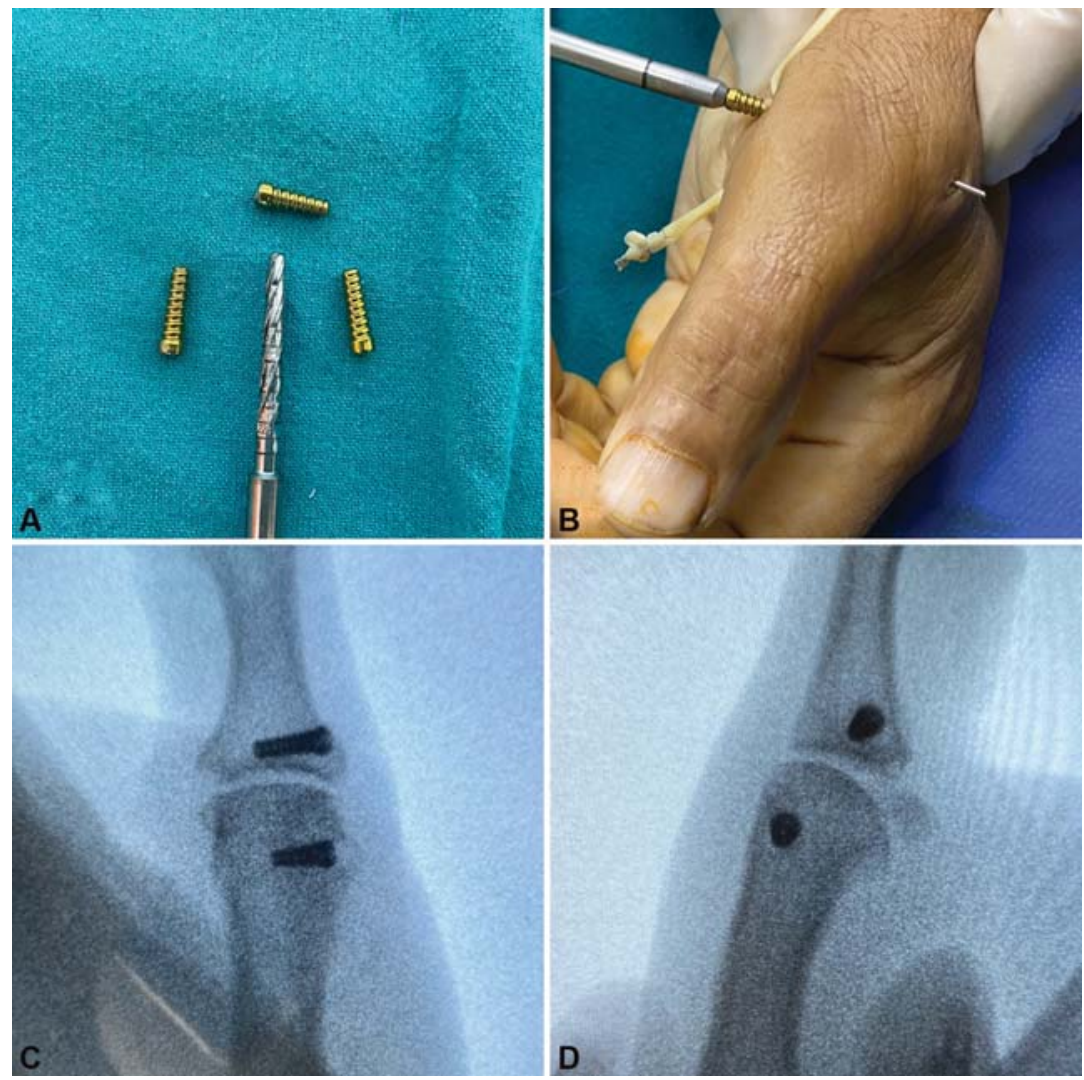

Fig. 4 Three-millimeter titanium tenodesis screws (A). Placement using guidewire (B). Intraoperative X-rays in frontal (C) and profile (D) views. 


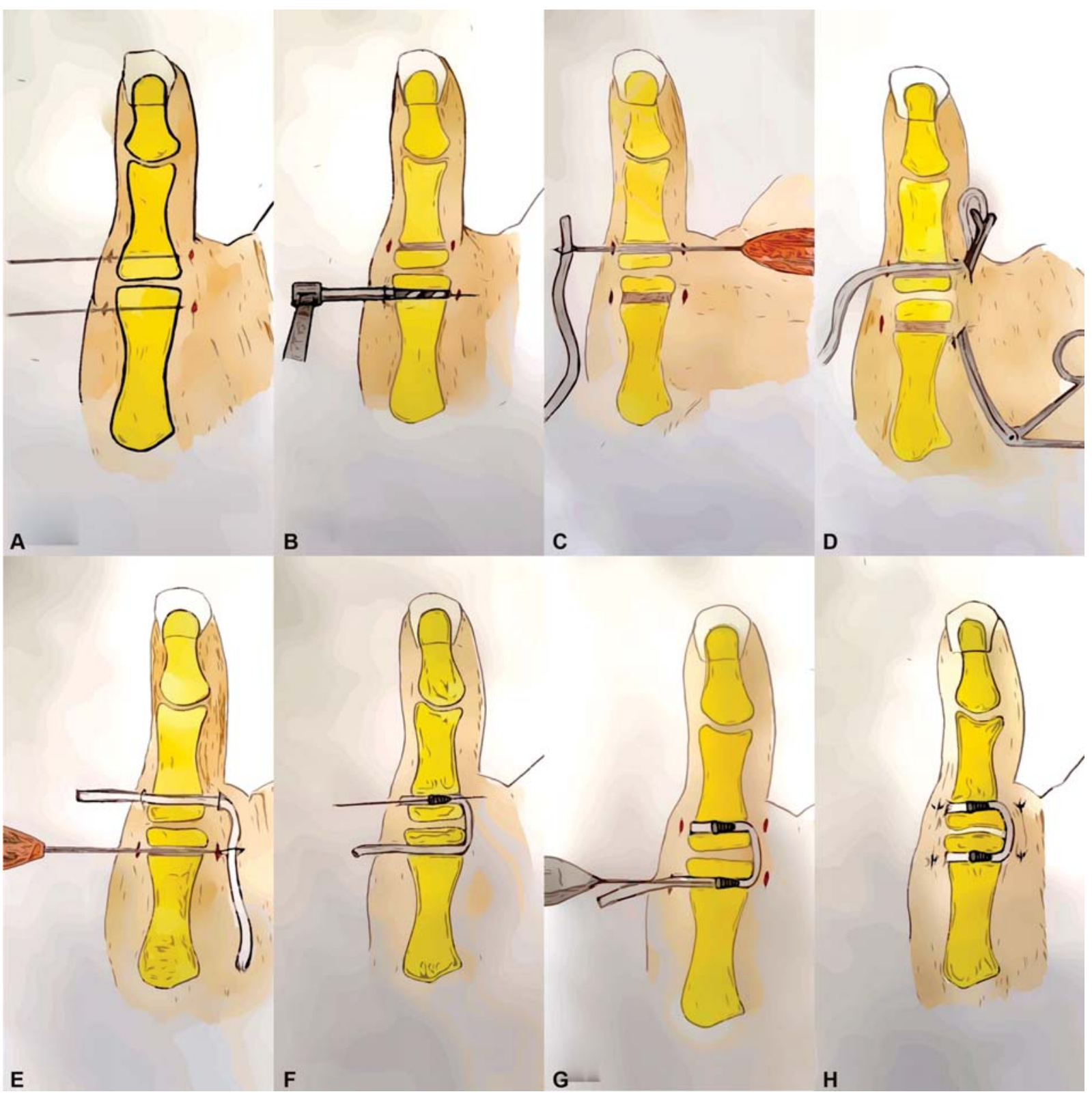

Fig. 5 Schematic representation of the surgical technique. (A) Placement of the Kirschner wires. (B) Drilling of the bone tunnels. (C) Tendon graft passage through the phalangeal tunnel. (D) Subcutaneous tunneling of the graft, from distal to proximal. (E) Graft passage through the metacarpal tunnel. (F) Placement of a 3-mm tenodesis screw in the phalanx. (G) Placement of a tenodesis screw in the metacarpal bone with maximum graft tension and metacarpophalangeal joint flexion of $30^{\circ}$. $(\mathrm{H})$ Outcome.

cadaveric study, Jiménez et al. ${ }^{23}$ compared UCL reconstruction with a tendon graft in a single band or a double band, and found comparable biomechanical properties and no significant differences in stability, joint congruence, mobility, valgus angle, and strength.

Our technique follows the Carlson et al. ${ }^{24}$ guidelines regarding the anatomical position of the tunnels and the use of interferential screws. However, we prefer to perform this technique percutaneously and to insert screws from the radial side to avoid graft tearing or weakening.

Although sensitive radial branches are distributed in a classical pattern on the back of the hand, there is anatomical diversity; ${ }^{25}$ this pattern was validated by Ropars et al. ${ }^{26}$ in an anatomical study of the superficial branches of the radial nerve in relation to the MCP arthroscopic portals at the thumb. These branches are exposed to injuries in both open surgery and arthroscopy; in addition, the MCP radial portal is not a safe approach. As such, we recommend the use of a soft-tissue protector during the drilling of bone tunnels and the placement of interference screws.

For these injuries, the outcomes of the surgical treatment are often favorable, regardless of the technique. ${ }^{27}$

\section{Conclusions}

This versatile and relatively easy surgical technique enables early mobilization, which, according to the preliminary results obtained six months after the procedure, leads to 
Table 1 Pre- and postoperative strength at the six-month follow-up

\begin{tabular}{|c|c|c|c|c|}
\hline $\begin{array}{l}\text { Gender, age of the patients, } \\
\text { and average values }\end{array}$ & Movement & $\begin{array}{l}\text { Preoperative } \\
\text { strength }(\mathrm{kg})\end{array}$ & $\begin{array}{l}\text { Postoperative } \\
\text { strength }(\mathrm{kg})\end{array}$ & $\begin{array}{l}\text { Normal contralateral } \\
\text { strength }(\mathrm{kg})\end{array}$ \\
\hline \multirow[t]{4}{*}{ Male, 51 years old } & Prehension (grip) & 16 & 30 & 32 \\
\hline & Key pinch & 6 & 14 & 14 \\
\hline & Palmar pinch & 2 & 8 & 8 \\
\hline & Tip pinch & 6 & 12 & 12 \\
\hline \multirow[t]{4}{*}{ Male, 25 years old } & Prehension (grip) & 25 & 38 & 38 \\
\hline & Key pinch & 6 & 14 & 15 \\
\hline & Palmar pinch & 2 & 7 & 9 \\
\hline & Tip pinch & 4 & 12 & 14 \\
\hline \multirow[t]{4}{*}{ Male, 33 years old } & Prehension (grip) & 28 & 40 & 45 \\
\hline & Key pinch & 8 & 13 & 15 \\
\hline & Palmar pinch & 4 & 7 & 8 \\
\hline & Tip pinch & 7 & 12 & 13 \\
\hline \multirow[t]{4}{*}{ Male, 38 years old } & Prehension (grip) & 20 & 38 & 42 \\
\hline & Key pinch & 6 & 13 & 13 \\
\hline & Palmar pinch & 3 & 6 & 8 \\
\hline & Tip pinch & 5 & 12 & 13 \\
\hline \multirow[t]{4}{*}{ Male, 41 years old } & Prehension (grip) & 28 & 35 & 36 \\
\hline & Key pinch & 5 & 11 & 12 \\
\hline & Palmar pinch & 2 & 6 & 7 \\
\hline & Tip pinch & 4 & 11 & 12 \\
\hline \multirow[t]{4}{*}{ Male, 24 years old } & Prehension (grip) & 24 & 38 & 40 \\
\hline & Key pinch & 8 & 14 & 14 \\
\hline & Palmar pinch & 5 & 8 & 9 \\
\hline & Tip pinch & 7 & 13 & 13 \\
\hline \multirow[t]{4}{*}{ Average values ( 35.3 years old) } & Prehension (grip) & $61 \%$ & $94.8 \%$ & $100 \%$ \\
\hline & Key pinch & $47 \%$ & $95 \%$ & $100 \%$ \\
\hline & Palmar pinch & $36 \%$ & $85.7 \%$ & $100 \%$ \\
\hline & Tip pinch & $42.8 \%$ & $93.5 \%$ & $100 \%$ \\
\hline
\end{tabular}

Table 2 Difference between pre- and postoperative mean strength

\begin{tabular}{|l|l|l|l|}
\hline & $\begin{array}{l}\text { Difference between pre- and } \\
\text { postoperative mean strength }(\mathrm{kg})\end{array}$ & $\begin{array}{l}\text { Standard } \\
\text { deviation }\end{array}$ & $\begin{array}{l}\text { p-value } \\
\text { (95\% confidence interval) }\end{array}$ \\
\hline Grip strength & 13 & 3.6 & 0.000 \\
\hline Key pinch & 6.6 & 1.2 & 0.000 \\
\hline Palmar pinch & 4 & 1.3 & 0.001 \\
\hline Tip pinch & 6.5 & 1.04 & 0.000 \\
\hline
\end{tabular}

a prompt recovery in strength parameters and complete joint mobility at the MCP joint of the thumb. Future investigations with larger samples and longer follow-up time are required to determine the effectiveness of this technique and to compare it to other procedures described in the literature
Conflict of interests

The authors have no conflict of interests to declare.

\section{Acknowledgments}

To Dr. José María Rotella, ${ }^{\dagger}$ who was, is and always will be a source of inspiration in this wonderful profession. 


\section{References}

1 Campbell CS. Gamekeeper's thumb. J Bone Joint Surg Br 1955;37$\mathrm{B}(01): 148-149$

2 Stener B. Displacement of the ruptured ulnar collateral ligament of the metacarpophalangeal joint of the thumb: a clinical and anatomic study. J Bone Joint Surg Br 1962;44:869-879

3 Lee AT, Carlson MG. Thumb metacarpophalangeal joint collateral ligament injury management. Hand Clin 2012;28(03):361-370, ix-X. Doi: 10.1016/j.hcl.2012.05.024

4 Tsiouri C, Hayton MJ, Baratz M. Injury to the ulnar collateral ligament of the thumb. Hand (N Y) 2009;4(01):12-18. Doi: 10.1007/s11552-008-9145-8

5 Lark ME, Maroukis BL, Chung KC. The Stener Lesion: Historical Perspective and Evolution of Diagnostic Criteria. Hand (N Y) 2017; 12(03):283-289. Doi: 10.1177/1558944716661999

6 Glickel SZ, Malerich M, Pearce SM, Littler JW. Ligament replacement for chronic instability of the ulnar collateral ligament of the metacarpophalangeal joint of the thumb. J Hand Surg Am 1993;18 (05):930-941

7 Neviaser RJ, Wilson JN, Lievano A. Rupture of the ulnar collateral ligament of the thumb (gamekeeper's thumb). Correction by dynamic repair. J Bone Joint Surg Am 1971;53(07):1357-1364

8 Fairhurst M, Hansen L. Treatment of "Gamekeeper's Thumb" by reconstruction of the ulnar collateral ligament. J Hand Surg $[\mathrm{Br}]$ 2002;27(06):542-545

9 Takagi T, Watanabe M. Ulnar Collateral Ligament Reconstruction of Thumb Metacarpophalangeal Joint With Adductor Pollicis Tendon Using the Wide-Awake Approach. J Hand Surg Am 2019;44(05):426.e1-426.e5. Doi: 10.1016/j.jhsa.2018.11.012

10 De Giacomo AF, Shin SS. Repair of the Thumb Ulnar Collateral Ligament With Suture Tape Augmentation. Tech Hand Up Extrem Surg 2017;21(04):164-166. Doi: 10.1097/BTH.0000000000000173

11 Wong TC, Ip FK, Wu WC. Bone-periosteum-bone graft reconstruction for chronic ulnar instability of the metacarpophalangeal joint of the thumb-minimum 5-year follow-up evaluation. J Hand Surg Am 2009;34(02):304-308. Doi: 10.1016/j.jhsa.2008.10.005

12 Selles RW, Zhou C, Kan HJ, Wouters RM, van Nieuwenhoven CA, Hovius SER. Percutaneous Aponeurotomy and Lipofilling versus Limited Fasciectomy for Dupuytren's Contracture: 5-Year Results from a Randomized Clinical Trial. Plast Reconstr Surg 2018;142 (06):1523-1531. Doi: 10.1097/PRS.0000000000004982

13 del Piñal F, Moraleda E, Rúas JS, de Piero GH, Cerezal L. Minimally invasive fixation of fractures of the phalanges and metacarpals with intramedullary cannulated headless compression screws. J Hand Surg Am 2015;40(04):692-700. Doi: 10.1016/j.jhsa.2014.11.023
14 Uçar BY. Percutaneous surgery: a safe procedure for trigger finger? N Am J Med Sci 2012;4(09):401-403. Doi: 10.4103/1947-2714.100988

15 Geissler WB. Cannulated percutaneous fixation of intra-articular hand fractures. Hand Clin 2006;22(03):297-305, vi

16 Greg Merrell and Joseph F. Slade. Dislocations and Ligament Injuries in the Digits. In: Green DP, Wolfe SW. Green's Operative Hands Surgery 6. ed. London: Churchill Livingstone; 2010:2392

17 Glickel SZ. Thumb metacarpophalangeal joint ulnar collateral ligament reconstruction using a tendon graft. Tech Hand Up Extrem Surg 2002;6(03):133-139

18 Wehbé MA. Tendon graft donor sites. J Hand Surg Am 1992;17 (06):1130-1132

19 Lee SK, Kubiak EN, Liporace FA, Parisi DM, lesaka K, Posner MA. Fixation of tendon grafts for collateral ligament reconstructions: a cadaveric biomechanical study. J Hand Surg Am 2005;30(05):1051-1055

20 Lee SK, Kubiak EN, Lawler E, Iesaka K, Liporace FA, Green SM. Thumb metacarpophalangeal ulnar collateral ligament injuries: a biomechanical simulation study of four static reconstructions. J Hand Surg Am 2005;30(05):1056-1060

21 Baskies MA, Tuckman D, Paksima N, Posner MA. A new technique for reconstruction of the ulnar collateral ligament of the thumb. Am J Sports Med 2007;35(08):1321-1325

22 Rettig A, Rettig L, Welsch M. Anatomic reconstruction of thumb metacarpophalangeal joint ulnar collateral ligament using an interference screw docking technique. Tech Hand Up Extrem Surg 2009;13(01):7-10. Doi: 10.1097/BTH.0b013e318184185e

23 Jimenez ML, Hioe SD, Kachooei AR, Shearin JW, Jones CM, Rivlin M. Single-Bundle vs Double-Bundle (Anatomical) Reconstruction of the Thumb Ulnar Collateral Ligament: Biomechanical Study. Hand (N Y) 2019;14(04):483-486. Doi: 10.1177/1558944717744338

24 Carlson MG, Warner KK, Meyers KN, Hearns KA, Kok PL. Mechanics of an anatomical reconstruction for the thumb metacarpophalangeal collateral ligaments. J Hand Surg Am 2013;38(01): 117-123. Doi: 10.1016/j.jhsa.2012.09.015

25 Tiznado G, Sousa-Rodrigues C, Olave E. Ramo superficial del nervio radial: Amplia distribución en el dorso de la mano. Int J Morphol 2012;30(02):374-378

26 Ropars M, Fontaine I, Morandi X, Berton E, Kaila R, Darnault P. Preserving the superficial branch of the radial nerve during carpometacarpal and metacarpophalangeal joint arthroscopy: an anatomical study. Surg Radiol Anat 2010;32(03):271-276. Doi: $10.1007 / \mathrm{s} 00276-010-0622-8$

27 Pulos N, Shin AY. Treatment of Ulnar Collateral Ligament Injuries of the Thumb: A Critical Analysis Review. JBJS Rev 2017;5(02): 01874474-201702000-00005. Doi: 10.2106/JBJS.RVW.16.00051 